\author{
SERIES 'UPDATE ON PULMONARY HYPERTENSION' \\ Edited by E. Weitzenblum and T. Higenbottam
}

\title{
The role of thrombosis in severe pulmonary hypertension
}

\author{
A. Chaouat*, E. Weitzenblum**, T. Higenbottam*
}

The role of thrombosis in severe pulmonary hypertension. A. Chaouat, E. Weitzenblum, T. Higenbottam. @ CERS Journals Ltd 1996.

ABSTRACT: Considering the important surface in pulmonary circulation where blood can interact with the endothelium, the maintenance of blood fluidity through the lung, by antithrombotic pathways and products of the endothelium, is essential. This function appears to be ineffective in primary pulmonary hypertension and in severe secondary pulmonary hypertension. Thrombotic lesions are frequently found in pulmonary arteries in these diseases.

Thrombin activity appears to be increased in severe pulmonary hypertension. Antithrombotic pathway disorders may account for this abnormality, particularly in chronic thromboembolic pulmonary hypertension and primary pulmonary hypertension. Injured endothelium, a constant feature in severe pulmonary hypertension, either primary or secondary, enhances thrombus formation in pulmonary vessels. This is probably related to thrombomodulin and tissue factor imbalance, impairment of prostacyclin and nitric oxide release, as well as inefficiency of fibrinolysis. Moreover, platelets appear to be activated in the pulmonary circulation of these patients. They release several mediators acting on vascular tone and as mitogenic agents, and may also contribute to thrombin and clot generation. Long-term oral anticoagulant and continuous infusion of prostacyclin, treatments which impede thrombosis, are known to improve the survival rate in patients with primary pulmonary hypertension.

These are the strongest arguments, so far, in favour of the role of thrombosis in severe pulmonary hypertension. However, we do not know whether these abnormalities result from a previous vascular injury or represent the primary disturbance.

Eur Respir J., 1996, 9, 356-363.
*Dept of Respiratory Physiology, Papworth Hospital, Cambridge, UK. **Dept of Pulmonology, Hôpital de Hautepierre, Strasbourg, France.

Correspondence: A. Chaouat

Service de Pneumologie

Hôpital de Hautepierre

Avenue Molière

67098 Strasbourg

France

Keywords: Coagulation fibrinolysis

platelets

pulmonary hypertension

pulmonary thrombosis

Received: October 171995

Accepted for publication November 31995

This work has been supported by an educational grant from Institut de Recherches Internationales Servier, Courbevoie, France, the British Heart Foundation, the Tobacco Products Research Trust. TH is the recipient of the HC Roscoe fellowship.
Blood coagulation and aggregation of platelets are essential processes in haemostasis. They are initiated locally when the integrity of the vasculature has been breached [1]. Generalized intravascular coagulation and thrombus formation are prevented by a series of natural anticoagulants $[2,3]$ and fibrinolysis, together with products of the endothelium, such as prostacyclin $\left(\mathrm{PGI}_{2}\right)$ [4], endothelium-derived nitric oxide (NO) [5], and tissuetype plasminogen activator (t-PA) [6].

The defects of proteins involved in the fibrinolytic system or in the inhibition of coagulation can result in a hypercoagulable state, which may lead to recurrent venous thromboembolism [7]. It has been suggested that this is also a factor in the development of chronic thromboembolic pulmonary hypertension (CTEPH) [8]. The same process may also be true in primary pulmonary hypertension (PPH) [9]. Consequently, it is important to increase our understanding of the role of thrombosis in severe pulmonary hypertension $(\mathrm{PH})$. This approach may, at least, explain some of the pathophysiology of severe $\mathrm{PH}$ and may offer therapeutic insight.

In this review, the focus will be the role of thrombosis in CTEPH, in PPH, in PH secondary to congenital cardiac defect, and in $\mathrm{PH}$ associated with antiphospholipid antibodies or connective tissue diseases. These entities have many features in common. We will first review the occurrence of thrombotic lesions in these diseases; and will then describe inherited or acquired disorders of anticoagulant functions and fibrinolysis, which may lead to thrombotic lesions in the pulmonary vasculature. The association of $\mathrm{PH}$ with platelet disorders and the occurrence of antiphospholipid (APL) antibodies will be described. Finally, the theoretical justification and the practical impact of anticoagulant therapy in severe $\mathrm{PH}$ will be discussed.

\section{Thrombotic lesions in pulmonary arteries}

Pulmonary arteries have a limited range of responses to injury, one is the formation of thrombi. These lesions can be acute or chronic when they appear as nonlaminar intimal fibrosis [10]. When such lesions predominate in pulmonary arteries, the term thrombotic pulmonary arteriopathy (TPA) is applied. 
A small number of such lesions is found in lungs of people without cardiac or pulmonary disease who are over the age of $40 \mathrm{yrs}$ [10]. By contrast, they are found much more commonly in all forms of severe PH. They affect approximately $75 \%$ of patients with CTEPH [11], and $50 \%$ of patients with PPH or PH caused by congenital cardiac defects [12]. In the American National Registry of PPH, 28 out of 58 (48\%) patients had thrombotic lesions in pulmonary arteries and 19 out of 58 (33\%) had TPA [13]. In other studies devoted to PPH, the frequency of TPA has ranged 20-56\% [9, 12, 14]. Furthermore, extensive central thrombi has recently been described in three PPH patients [15]. Although the occurrence of thromboemboli is excluded by definition in PPH, thrombotic lesions and TPA are among the most frequent histopathological appearance in this disease, and, consequently, they are probably the result of local thrombosis.

Although, thrombotic lesions in pulmonary arteries and TPA have never been correlated with the severity of PH, the studies quoted above have shown that in all forms of severe PH, thrombotic lesions could be found in pulmonary arteries. These observations provide a starting point in the discussion of the role of thrombosis in severe $\mathrm{PH}$.

\section{The mechanism and consequence of increased thrombin activity}

The complex process involved in blood coagulation can be simplified into a series of linked reactions in which a number of enzymes, zymogens, are activated. These reactions take place on the surface of cell membranes, e.g. platelets, endothelial cells and inflammatory cells. Transformations are accelerated by nonenzyme protein co-factors, which either cause conformational changes or bind the zymogens to cell surfaces. There are two coagulation pathways (fig. 1), intrinsic and extrinsic [1]. The latter is initiated by tissue factor (TF) and circulating factors VII and VIIa (a=activated) [16]. Both pathways converge with the binding of activated factors $\mathrm{X}$ and $\mathrm{V}$ to the cell surface endothelium or

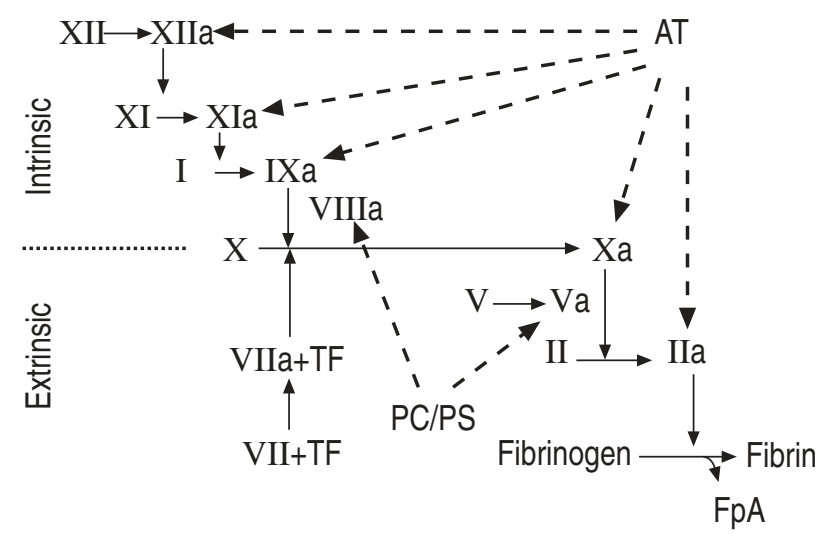

Fig. 1. - Coagulation cascade and antithrombotic pathways (dashed arrows). II, V, VII, VIII, IX, X, XI, XII: coagulation factors; a: activated; AT: antithrombin; FpA: fibrinopeptide A; PC: protein C; PS: protein $\mathrm{S}$; TF: tissue factor.

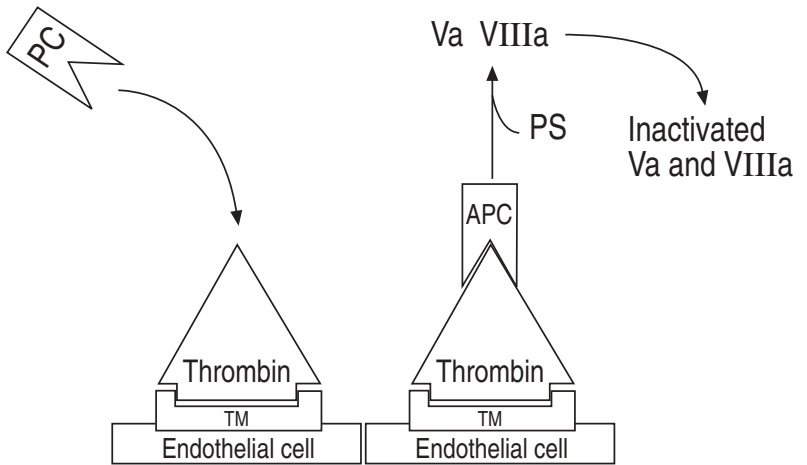

Fig. 2. - Anticoagulant protein $\mathrm{C}$ system. APC: activated protein C; TM: thrombomodulin. For further abbreviations see legend to figure 1.

platelets to form the prothrombinase complex $(\mathrm{Xa}+\mathrm{Va})$. This enzyme converts circulating prothrombin into thrombin. Finally, thrombin is responsible for converting fibrinogen to fibrin and releasing fibrinopeptide A (FpA).

There are a series of circulating inhibitors which prevent blood coagulation. They inhibit intravascular coagulation and normally limit any coagulation to a local site of injury. The first deficiency of these factors described, and probably the most important one, is the deficiency of antithrombin (AT). This factor inactivates thrombin, and also inhibits the other serine proteases, including factors XIIa, XIa, IXa and Xa [2]. AT causes inhibition by the formation of a stable 1:1 molar complex between the enzyme active site and AT at its arginine amino acid residue in position 385 , or at the serine residue in position 386. Heparin binds at different sites on AT. It is thought to produce marked conformational change in AT. This enhances the ability of AT to inhibit thrombin and Xa. Heparin co-factor II is also a heparin-dependent plasma inhibitor of thrombin. It acts independently of AT, being less effective, and may also be deficient in certain individuals $[17,18]$.

Activated protein C (APC) is another natural anticoagulant [3] (fig. 2). When circulating, thrombin binds to a protein expressed on the surface of endothelial cells, called thrombomodulin. The product is a powerful activator of protein $\mathrm{C}$. APC shears factor $\mathrm{Va}$ at arginine amino acid residue in position 506, causing inactivation. By so doing, it blunts both the extrinsic and intrinsic coagulation pathways at the crucial prothrombinase complex. Protein $\mathrm{S}$ is a cofactor required for the factor $\mathrm{Va}$ and VIIIa inactivation by APC and may also be deficient.

There is evidence that intravascular coagulation in the pulmonary circulation may be a continuous process in patients with severe PH. The level of FpA is a measure of thrombin activity. EISENBERG et al. [19] reported that FpA was abnormal in all PPH patients and was markedly elevated in $61 \%$. Moreover, in one PPH patient a gradient of FpA level was found across the lung [20]. In a family of PPH patients with abnormal haemoglobin, elevated FpA was also observed [21]. This was associated with evidence of TPA on lung histology [22]. Although, FpA can be raised in both secondary PH and $\mathrm{PPH}$, we do not know if these changes are a result rather than the cause of the pulmonary vascular disease. 


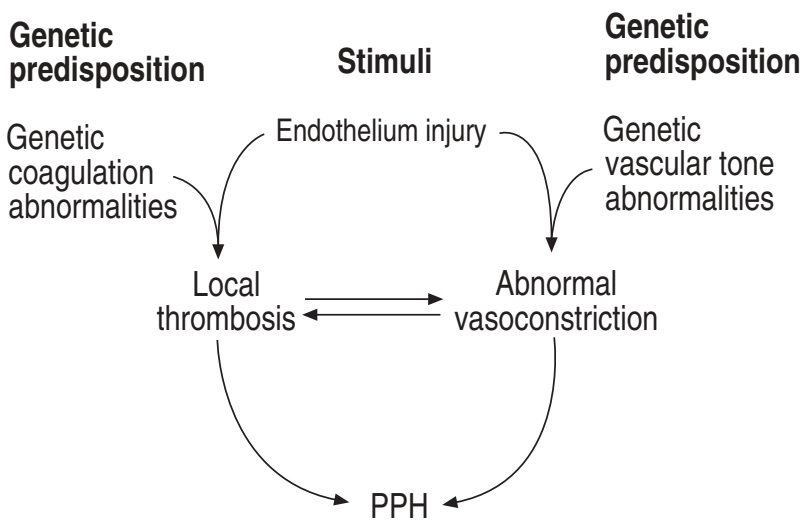

Fig. 3. - Hypothetical role of genetic abnormalities in the pathophysiology of primary pulmonary hypertension. PPH: primary pulmonary hypertension.

It can be questioned whether a deficiency of antithrombotic pathways could contribute to the pathogenesis in patients with severe $\mathrm{PH}$. These deficiencies are now well-described and their genetics are known. Indeed, deficiencies of AT, heparin co-factor II, or of protein C and protein $\mathrm{S}$ can be expected in about $5 \%$ of patients with symptomatic thrombotic disease (deep vein thrombosis or pulmonary emboli) [7]. Furthermore, a new mechanism of familial thrombosis has recently been described [23]. It involves APC resistance due to a mutation in the factor $\mathrm{V}$ gene. This mutation results in replacement of arginine in position 506 with a glutamine amino acid residue. Since APC cleaves factor $\mathrm{Va}$ at arginine in position 506, the mutated factor Va has normal procoagulant activity, but is resistant to APC [24].

In a consecutive series of patients with venous thrombosis or thromboembolic disease, approximately $40 \%$ had APC resistance [25]. This is much higher than all other deficiencies of the antithrombotic pathways [7]. The prevalence in a control population is 3-7\% [26], suggesting that the factor $\mathrm{V}$ mutation is quite common. Familial studies have suggested an autosomal dominant mode of inheritance for these antithrombotic pathway deficiencies [27]. However, the high frequency of heterozygous protein $\mathrm{C}$ deficiency and heterozygous APC resistance in an asymptomatic general population is not in agreement with a dominant mode of inheritance, unless external factors are important. It is possible that these antithrombotic pathway deficiencies in themselves are relatively weak risk factors for thrombosis, and that the risk is enhanced only if they are associated with other genetic or acquired risk factors, such as a surgical procedure or major injury. The pathogenesis of PPH is supposed to be quite similar and can be characterized by the occurrence of various stimuli which may initiate the development of vascular lesions in predisposed patients [28]. One can suppose that this susceptibility may be an anti-thrombotic pathway disorder in some patients with PPH (fig. 3).

Therefore, it is well-known that patients with AT, protein $\mathrm{C}$, or protein $\mathrm{S}$ deficiencies, or resistance to APC have a high risk of developing deep venous thrombosis and pulmonary embolism. We must await further studies in order to establish the prevalence of such deficiencies in patients with severe $\mathrm{PH}$ and whether these inherited deficiencies of coagulation contribute either to $\mathrm{PPH}$ or to CTEPH.

\section{Injured endothelium}

Endothelium participates actively in the process of coagulation. Indeed, STERN et al. [29] showed that the endothelium is capable of sustaining the activation of factor X. Moreover, the binding on the endothelial surface of the enzyme IXa is augmented by the addition of co-factor (VIII) and the substrate (X). Notably, factors IX and $\mathrm{X}$ act at the junction of the intrinsic and extrinsic pathways. Another important step in coagulation is the formation of the prothrombinase complex $(\mathrm{Xa}+\mathrm{Va})$. It is demonstrated that this complex is not only bound on membrane of platelets but also on the surface of endothelial cells (fig. 4) [30]. The endothelium can also act at the level of TF expression, which is the exclusive point of control of the extrinsic pathway of the coagulation. It is known that cytokines increase TF expression by endothelial cells, which increase thrombotic activity by initiating the extrinsic pathway of the coagulation [31,32]. As endothelial cells are injured in severe $\mathrm{PH}$, these functions must be affected; however, little is known about them in patients with $\mathrm{PH}$. This must represent a further important area for investigation.

Von Willebrand Factor (vWF) is a glycoprotein which plays an important role in primary haemostasis. It

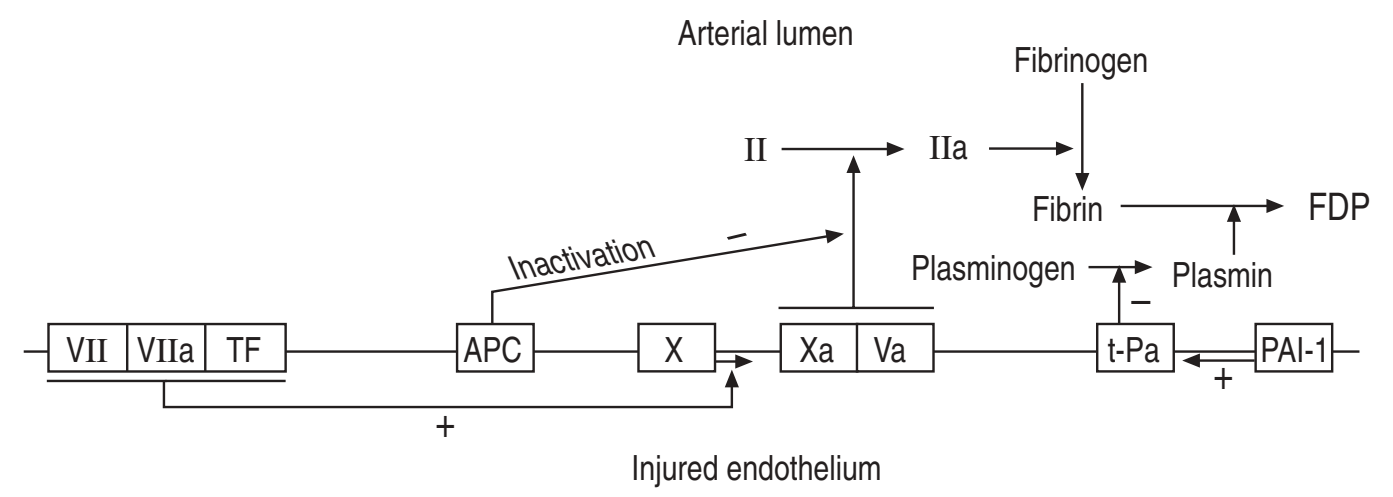

Fig. 4. - Procoagulant activity and defect in fibrinolysis expressed by injured pulmonary endothelium. +: increased pathways when the endothelium is injured; -: depressed pathways when the endothelium is injured; FDP: fibrinogen degradation products; PAI-1: plasminogen activator inhibitor type-1; t-PA: tissue-type plasminogen activator. For further abbreviations see legends to figures 1 and 2. 
functions as an adhesive protein for platelets to the vessel wall, as well as a carrier for factor VIII. The release of vWF from endothelial cells is carried out by the formation of storage granules termed Weibel-Pelade bodies, which contain multimers of $\mathrm{vWF}$, or directly as pro-vWF dimers [33]. In PH secondary to congenital heart disease and in $\mathrm{PPH}$, the expression of vWF is increased $[34,35]$. These patients also exhibit abnormal vWF multimer pattern [36], possibly due to degradation of vWF main subunit [37]. These abnormalities of vWF may be related to endothelial cell injury and may cause a decrease of platelet aggregation to ristocetin, since these multimers of vWF are defective. This suggests that platelet adhesion to vessel walls, involving vWF, is decreased in pulmonary hypertensive patients. However, $\mathrm{vWF}$ binding is only one aspect of platelet adhesion to subendothelium in pulmonary hypertensive patients. For instance, platelet-activating factor is released by injured endothelial cells and can itself activate platelets and cause an adhesion to the vascular wall [38].

The endothelium has not only procoagulant functions. Endothelial cells actively contribute to prevention of thrombosis by inhibiting platelet aggregation. Two powerful vasodilators, $\mathrm{PGI}_{2}$ and $\mathrm{NO}$, are synthesized and released by endothelial cells. They both inhibit platelet aggregation and can also reverse the process $[4,5]$. There is now evidence of impaired release of $\mathrm{PGI}_{2}$ [39] and $\mathrm{NO}$ [40] by endothelial cells of pulmonary arteries in patients with primary and secondary $\mathrm{PH}$ (fig. 5). This can be considered as a further mechanism by which thrombosis can be enhanced in pulmonary circulation.

Thrombomodulin is produced by endothelial cells. It is a membrane-bound co-factor with a high affinity receptor for thrombin, rendering it incapable of cleaving fibrinogen

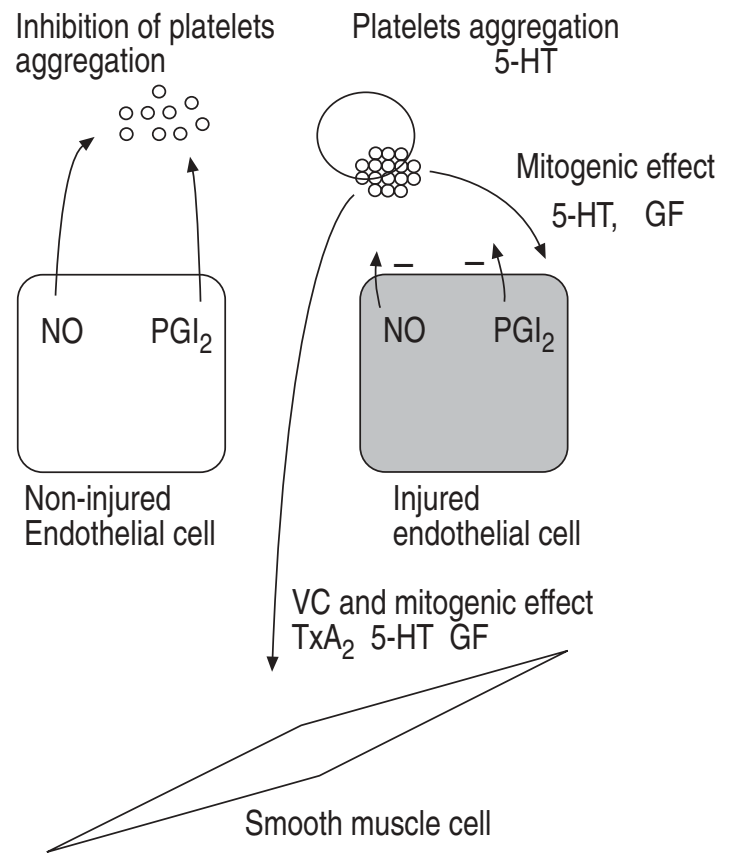

Fig. 5. - Interaction between platelets, endothelial cells and smooth muscle cells in severe pulmonary hypertension. -: depressed functions when the endothelium is injured. 5-HT: serotonin; GF: growth factors; NO: nitric oxide; $\mathrm{PGI}_{2}$ : prostacyclin; $\mathrm{TxA}_{2}$ : thromboxane $\mathrm{A}_{2}$; VC: vasoconstriction. or activating platelets. Furthermore, it rapidly converts protein C to APC (fig. 2). This is another method by which endothelial cells are able to avoid clot formation. Thrombomodulin production is reduced when endothelial cells are exposed to cytokines [41, 42]. Thus, cytokine exposure creates an imbalance between thrombomodulin and TF production by endothelial cells, and may promote coagulation in pulmonary vessels. Recently, two studies have shown, firstly, an increase in the serum levels of two cytokines, interleukin 1 and 6 (IL-1 and IL-6) [43], and, secondly, a significant decrease of thrombomodulin [44] in patients with PPH.

The endothelium also has an important role at the level of fibrinolysis, since endothelial cells are a source of t-PA [6]. The endothelium releases t-PA both continuously and acutely in response to triggering factors. Endothelial cells of pulmonary arteries play a part in the continuous production of t-PA. Since t-PA has only limited activity on a pre-existing fibrin clot, acute and local production of t-PA plays a major role in fibrinolysis and, thus, maintains a thromboresistant state in the pulmonary circulation. Notably, endothelial cells also synthesise and release plasminogen activator inhibitor type-1 (PAI-1), which inhibits t-PA by rapid formation of enzyme inhibitor complex. In fact, plasminogen activator inhibitors are rapidly converted to an inactive latent form [45]. However, the mechanism regulating the conversion remains unknown.

EISENBERG et al. [19] found an increase of PAI-1 in plasma of 17 out of 29 PPH patients. Although the plasma concentration of t-PA was not decreased, the t-PA level in pulmonary circulation may be insufficient to induce fibrinolysis in the face of increased PAI-1 activity. These authors suggested that, in patients with $\mathrm{PPH}$, thrombosis may be exacerbated by inadequate fibrinolytic activity. In CTEPH, it is known that a failure to resolve thrombi leads to development of $\mathrm{PH}$ [46]. A recent study [47] showed a significant increase of t-PA and PAI-1 antigen in "resting" plasma (before venous occlusion) of 32 patients with CTEPH compared to agematched control subjects, and a greater increase in plasma t-PA antigen and activity in response to venous occlusion. Therefore, in spite of fibrinolytic abnormalities in these patients, the authors did not find a blunted response of t-PA or plasminogen activator activity to venous occlusion to explain the failure to resolve thrombi in pulmonary arteries. Similarly, Schulman et al. [48] did not find abnormalities in lytic mechanisms in 10 patients with PPH and seven patients with secondary PH compared to nine normal volunteers. Conversely, HubER et al. [49] found that patients with PPH and CTEPH exhibited a decreased t-PA level and an increased PAI-1 level after venous occlusion compared with healthy subjects (fig. 4).

In experimental models of endothelial injury, the role of fibrinolysis is also debated. Schultze and Roth [50] found no change in fibrinolytic properties of cultured pulmonary endothelial cells exposed to monocrotaline; however, the same authors [51] reported a decrease of fibrinolytic activity of rat lung tissue after exposure to monocrotaline. 
Whilst several arguments lead us to suppose that coagulation is activated in the pulmonary circulation of patients with severe $\mathrm{PH}$, a blunted fibrinolytic response has not yet been convincingly demonstrated.

\section{Platelets}

In the normal state, platelets circulate through the lungs in an inactive form and display little inclination to interact with pulmonary microcirculation. However, when platelets are activated they become a catalytic surface for coagulation and release numerous mediators [52, 53]. These mediators interact particularly with endothelial cells, neutrophils, fibroblasts and smooth muscle cells. Once activated, there is a complex co-operative interaction between these cells, which can result in either maintenance of normal lung function or a contribution to structural alteration of the lung by means of procoagulant, vasoactive and mitogenic mediators $[54,55]$.

Arguments for the role of activated platelets in $\mathrm{PH}$ in creating thrombi in the pulmonary vasculature have come from experimental models. Vascular thrombi are usually found in the pulmonary vessels after using monocrotaline to injure the lung and cause $\mathrm{PH}$ [56]. The presence of platelets in the thrombi and the fact that experimentally induced thrombocytopenia can reduce the development of $\mathrm{PH}$ [57] suggests that platelets play a role in the occurrence of PH. Perhaps the thrombosis itself contributes to PH. Clinical studies also reveal conflicting results. Two studies [20,39] have shown an increase in amounts of the markers of platelet activation; whereas, another study [48] reported no difference in these markers between patients with primary or severe secondary $\mathrm{PH}$ and normal volunteers.

In addition to their role in coagulation, platelets appear to play an important part in the pathogenesis of severe $\mathrm{PH}$. When activated, they are known to release the powerful vasoconstrictor thromboxane $\mathrm{A}_{2}\left(\mathrm{TxA}_{2}\right)$. It is of importance that in patients with PPH or severe secondary $\mathrm{PH}, \mathrm{TxA}_{2}$ production is elevated; this is probably platelet derived [39]. In addition to $\mathrm{TxA}_{2}$, platelets also release many other substances, including serotonin (5HT), platelet-derived growth factor, epidermal growth factor and transforming growth factor- $\beta$ [55]. These have a powerful mitogenic effect on vascular smooth muscle cells [58, 59], fibroblasts and endothelial cells [60]. It is reasonable to suspect that they induce the remodelling of pulmonary vasculature, which occurs in severe secondary or primary PH. Serotonin which is stored in platelets is a mitogenic factor and a weak pulmonary vasoconstrictor [61]. Serotonin also potentiates the mitogenic effect of growth factors [62]. HeRve et al. [63] described a patient suffering from a familial platelet storage pool disease associated with PPH. Since the platelets of this patient exhibited a deficiency in ability to store 5-HT in dense granules, the free level of 5-HT was high. In a further study, they demonstrated elevated 5-HT levels in the plasma of patients with PPH, which remained after lung transplantation suggesting a primary abnormality [64]. These data assume special importance, as the 5-HT uptake inhibitors, fenfluramine and dexfenfluramine, have been associated with the development of PPH $[65,66]$.

Whilst the evidence for a contribution by platelets in local pulmonary thrombosis to the development of severe $\mathrm{PH}$ is weak, there is an emerging role of platelet-selective release of mediators, such as 5-HT, TxA $\mathrm{A}_{2}$ and growth factors, occurring in patients with severe $\mathrm{PH}$ (fig. 5). Future work needs to be devoted to the relationship of these mediators and local thrombosis in the pulmonary circulation.

\section{Antiphospholipid antibodies}

The presence in plasma of APL antibodies is one of the more common causes of acquired thrombophilia [67]. These antibodies can be found either in patients suffering from systemic lupus erythematosus (SLE) or mainly in patients without biological and clinical criteria for SLE but associated with a history of venous and/or arterial thrombosis. The latter patients may not have accompanying thrombocytopenia [68]. Various potential mechanisms have been proposed to explain the increased risk of thrombosis in SLE and APL syndrome. These include a decrease in the plasma level of free protein $S$ [69], and the occurrence of a plasma inhibitor of endothelial activation of protein $\mathrm{C}$ [70]. A plasma inhibitor of factor Va degradation [71], increased plasma level of PAI-1 [72], and a plasma factor which inhibits endothelial cell release and/or production of $\mathrm{PGI}_{2}$ [73] have also been reported. A recent in vitro study has shown an increase of platelet aggregation and adherence to the subendothelium, as well as an increase in immunoglobulin binding to platelets in the presence of APL [74]. These observations remain doubtful when considering a mechanism which is active in vivo, particularly the potential inhibition of $\mathrm{PGI}_{2}$ production by endothelial cells [75].

PPH and CTEPH have been well described in APL syndrome [76, 77]. However, it is an uncommon complication of APL syndrome. In a multi-centre study of 70 patients suffering from APL syndrome [68], 18 patients had pulmonary embolism but only two had PH (one related to pulmonary embolism and the other resembling the PPH). Moreover, Asheron et al. [78] reported 24 patients with $\mathrm{PH}, 22$ had SLE, one primary APL syndrome, and one SLE/progressive systemic sclerosis "overlap syndrome". It is interesting to note that 17 out of 24 patients $(67 \%)$ had APL antibodies, which is higher than expected in SLE patients without PH. In the same study, the prevalence of $\mathrm{PH}$ in these patients was about $5 \%$. Conversely, Olman et al. [47], in 32 consecutive patients with surgically documented CTEPH, found antiphospholipid antibodies in only two patients.

Thus, an association between APL antibodies and PH, though uncommon, is well-established. In some patients, there is a link between thrombosis in pulmonary arteries and the occurrence of $\mathrm{PH}[78,79]$. We must emphasize that in this disease the presence of APL antibodies and, subsequently, thrombosis in pulmonary arteries may be the primary cause of PH. These data justify the screening of patients with PPH and CTEPH for APL antibodies. 


\section{Anticoagulant therapy}

Since several studies have shown an increase of thrombin activity $[19,21]$ and an activation of platelets in severe PH [39], as well as a decrease of the thromboresistant nature of injured endothelium [44, 49], anticoagulant therapy may be justified in these patients. A further major reason to prescribe an anticoagulant therapy in severe $\mathrm{PH}$ is not related to the pathogenesis of $\mathrm{PH}$ but to its consequences on haemodynamic status. It is well-known that patients with severe $\mathrm{PH}$ have a low cardiac output, and low flow states are a major risk factor in development of lethal thromboembolism disease [8].

Long-term oral anticoagulant therapy has been assessed in PPH with respect to survival. FUSTER et al. [80] first observed an improvement in survival of PPH patients on warfarin or coumadin. RicH et al. [81] compared PPH patients on warfarin with those on no long-term anticoagulant therapy. They reported enhanced survival in the treated patients. A retrospective study on the survival of pulmonary hypertensive patients who had taken the dietary suppressant aminorex [82] also showed that anticoagulant therapy increased survival rates. This effect was greater when the treatment was initiated early after the first symptoms. Furthermore, 2 out of 3 of these patients treated with warfarin experienced restoration of functional and haemodynamic status.

An alternative to formal anticoagulation is the use of antiplatelet treatments. $\mathrm{PGI}_{2}$ is a powerful vasodilator but also inhibits platelet aggregation and inhibits smooth muscle proliferation [4]. The latter effect has been suggested to be the consequence of inhibition of platelet aggregation on vessel walls [62]. Long-term infusion of $\mathrm{PGI}_{2}$ was first tested in the UK $[83,84]$. This treatment improved survival rates of PPH patients [85]. It should be emphasized that $\mathrm{PGI}_{2}$ had its greatest effect on survival in those patients with the poorest vasodilatory capacity. Long-term heparin has never been evaluated in these patients. Survival improvement under long-term anticoagulant therapy is not necessarily due to prevention of local thrombosis in pulmonary vessels. Warfarin also prevents fatal thromboembolism, and $\mathrm{PGI}_{2}$ is also a powerful vasodilator and inhibits smooth muscle cell proliferation. These separate roles of the two agents would also account for their efficiency in improvement of survival. Whatever the mechanism involved, anticoagulant therapy may be warranted in all patients with $\mathrm{PPH}[28,81]$. $\mathrm{PGI}_{2}$ is reserved for those with the worst chance of survival [86]. CTEPH and PH associated with APL antibodies also requires long-term anticoagulant therapy. As regards PH secondary to cardiac defect, anticoagulant therapy must not be prescribed, as these patients have a greater risk for haemoptysis.

In conclusion, the pulmonary vascular endothelium plays an important role in maintaining blood fluidity through the lung. Studies have shown an impairment of this function in patients with PPH or severe secondary $\mathrm{PH}$. Local thrombosis can result, which has been confirmed by the appearance of increased thrombin activity in these patients, as well as platelet activation. Several mechanisms have been involved. There is an imbalance between thrombomodulin and TF when pulmonary endothelial cells are stimulated by cytokines. An increased blood level of $\mathrm{TxA}_{2}$ has also been well-demonstrated in these patients. The elevated level of $\mathrm{TxA}_{2}$ is probably plateletderived. Furthermore, there is now evidence of impaired release of $\mathrm{PGI}_{2}$ and $\mathrm{NO}$ by endothelial cells of pulmonary arteries in patients with primary and secondary $\mathrm{PH}$. These mediators do not act only on the vascular tone but also increase local thrombosis in the pulmonary circulation when their release by endothelial cells are impaired. Finally, the presence of APL antibodies, a common cause of thrombophilia, appears to be implied in the occurrence of $\mathrm{PH}$. These are the strongest arguments, so far, for the role of thrombosis in severe $\mathrm{PH}$.

With the exception of PH secondary to cardiac defect and PH associated with APL antibodies, in which these abnormalities of coagulation represent, respectively, a consequence or the cause of $\mathrm{PH}$, it is unknown whether they characterize causal mechanisms or simply epiphenomena. Further work must be performed, in particular to establish the relationship between severe $\mathrm{PH}$ and antithrombotic pathway disorders and the exact roles of fibrinolysis and platelets in these diseases.

The isolation of risk factor of PPH or CTEPH related to coagulation should lead to a better understanding of the pathophysiology. This would make it possible to treat these coagulation abnormalities in order to avoid further damage to the lung.

\section{References}

1. Colman RW, Marder VJ, Salzman EW, Hirsh J. Overview of hemostasis. In: Colman RW, Hirsh J, Marder VJ, Salzman EW, eds. Hemostasis and Thrombosis: Basic Principles and Clinical Practice. Third edn. Philadelphia, J.B. Lippincott Co. 1994; pp. 3-18.

2. Perry DJ. Antithrombin and its inherited deficiencies. Blood Rev 1994; 8: 37-55.

3. Dahlback B. The protein C anticoagulant system: inherited defects as basis for venous thrombosis. Thromb Res 1995; 77: 1-43.

4. Moncada S, Vane JR. Arachidonic acid metabolites and the interactions between platelets and blood vessel walls. N Engl J Med 1979; 300: 1142-1147.

5. Moncada S, Palmer RM, Higgs EA. Nitric oxide: physiology, pathophysiology and pharmacology. Pharmacol Rev 1991; 43: 109-142.

6. Loskutoff DJ, Edgington TE. Synthesis of a fibrinolytic activator and inhibitor by endothelial cells. Proc Natl Acad Sci USA 1977; 74: 3903-3907.

7. Heijboer H, Brandjes DP, Buller HR, Sturk A, ten Cate JW. Deficiencies of coagulation-inhibiting and fibrinolytic proteins in out-patients with deep-vein thrombosis. N Engl J Med 1990; 323: 1512-1516.

8. Moser K. Venous thromboembolism: state of the art. Am Rev Respir Dis 1990; 141: 235-249.

9. Bjornsson J, Edwards WD. Primary pulmonary hypertension: a histopathologic study of 80 cases. Mayo Clin Proc 1985; 60: 16-25.

10. Wagenvoort CA, Mulder PH. Thrombotic lesion in primary plexogenic arteriopathy: similar pathogenesis or complication? Chest 1993; 103: 844-849.

11. Moser KM, Bloor CM. Pulmonary vascular lesions 
occurring in patients with chronic major vessel thromboembolic pulmonary hypertension. Chest 1993; 103: 685-692.

12. Wagenvoort CA. Lung biopsy specimens in the evaluation of pulmonary vascular disease. Chest 1980; 77: 614-625.

13. Pietra GG, Edwards WD, Kay JM, et al. Histopathology of primary pulmonary hypertension: a qualitative and quantitative study of pulmonary blood vessels from 58 patients in the National Heart, Lung, and Blood Institute, Primary Pulmonary Hypertension Registry. Circulation 1989; 80: 1198-1206.

14. Wagenvoort CA, Wagenvoort N. Primary pulmonary hypertension: a pathologic study of the lung vessels in 156 clinically diagnosed cases. Circulation 1970; 42: $1163-1181$.

15. Moser KM, Fedullo PF, Finkbeiner WE, Golden J. Do patients with primary pulmonary hypertension develop extensive central thrombi? Circulation 1995; 91: 741745.

16. Nemerson Y. The tissue factor pathway of blood coagulation. In: Colman RW, Hirsh J, Marder VJ, Salzman EW, eds. Hematostasis and Thrombosis: Basic Principles and Clinical Practice. Third edn. Philadelphia, J.B. Lippincott Co., 1994; pp. 81-93.

17. Tran TH, Marbet GA, Duckert F. Association of hereditary heparin co-factor II deficiency with thrombosis. Lancet 1985; ii: 413-414.

18. Sie P, Dupouy D, Pichon J, Boneu B. Constitutional heparin co-factor II deficiency associated with recurrent thrombosis. Lancet 1985; ii: 414-416.

19. Eisenberg PR, Lucore C, Kaufman L, Sobel BE, Jaffe AS, Rich S. Fibrinopeptide A levels indicative of pulmonary vascular thrombosis in patients with primary pulmonary hypertension. Circulation 1990; 82: 841-847.

20. Rostagno C, Prisco D, Abbate R, Poggesi L. Pulmonary hypertension associated with long-standing thrombocytosis. Chest 1991; 99: 1303-1305.

21. Rich S, Hart K. Familial pulmonary hypertension in association with an abnormal hemoglobin: insights into the pathogenesis of primary pulmonary hypertension. Chest 1991; 99: 1208-1210.

22. Rich S, Pietra GG, Kieras K, Hart K, Brundage BH. Primary pulmonary hypertension: radiographic and scintigraphic patterns of histologic subtypes. Ann Intern Med 1986; 105: 499-502.

23. Dahlback B, Carlsson M, Svensson PJ. Familial thrombophilia due to a previously unrecognized mechanism characterized by poor anticoagulant response to activated protein C: prediction of a co-factor to activated protein C. Proc Natl Acad Sci USA 1993; 90: 1004-1008.

24. Bertina RM, Koeleman BP, Koster T, et al. Mutation in blood coagulation factor $\mathrm{V}$ associated with resistance to activated protein C. Nature 1994; 369: 64-67.

25. Svensson PJ, Dahlback B. Resistance to activated protein $\mathrm{C}$ as a basis for venous thrombosis. $N \mathrm{Engl} \mathrm{J} \mathrm{Med}$ 1994; 330: 517-522.

26. Reitsma PH, Poort SR, Bernardi F, et al. Protein C deficiency: a database of mutations. Thromb Haemost 1993; 69: 77-84.

27. Bovill EG, Bauer KA, Dickerman JD, Callas P, West B. The clinical spectrum of heterozygous protein $\mathrm{C}$ deficiency in a large New England kindred. Blood 1989; 73: 712-717.

28. Rubin LJ. Primary pulmonary hypertension. Chest 1993; 104: 236-250.

29. Stern DM, Nawroth PP, Kisiel W, Vehar G, Esmon CT.
The binding of factor IXa to cultured bovine aortic endothelial cells: induction of a specific site in the presence of factors VIII and X. J Biol Chem 1985; 260: 67176722.

30. Rodgers GM, Greenberg CS, Shuman MA. Characterization of the effects of cultured vascular cells on the activation of blood coagulation. Blood 1983; 61: 1155-1162.

31. Prydz H, Pettersen KS. Synthesis of thromboplastin (tissue factor) by endothelial cells. Haemostasis 1988; 18 : 215-223.

32. Conway EM, Bach R, Rosenberg RD, Konigsberg WH. Tumor necrosis factor enhances expression of tissue factor mRNA in endothelial cells. Thromb Res 1989; 53: 231-241.

33. Girma JP, Meyer D, Verweij CL, Pannekoek H, Sixma JJ. Structure-function relationship of human von Willebrand factor. Blood 1987; 70: 605-611.

34. Rabinovitch M, Andrew M, Thom $\mathrm{H}$, et al. Abnormal endothelial factor VIII associated with pulmonary hypertension and congenital heart defects. Circulation 1987; 76: 1043-1052.

35. Geggel RL, Carvalho AC, Hoyer LW, Reid LM. Von Willebrand factor abnormalities in primary pulmonary hypertension. Am Rev Respir Dis 1987; 135: 294-299.

36. Lopes M, Maeda NY, Aiello VD, Ebaid M, Bydlowski SP. Abnormal multimeric and oligomeric composition is associated with enhanced endothelial expression of von Willebrand factor in pulmonary hypertension. Chest 1993; 104: 1455-1460.

37. Lopes AAB, Maeda NY. Abnormal degradation of von Willebrand factor main subunit in pulmonary hypertension. Eur Respir J 1995; 8: 530-536.

38. George JN, Pickett EB, Saucerman S, et al. Platelet surface glycoproteins. J Clin Invest 1986; 78: 340-348.

39. Christman BW, McPherson CD, Newman JH, et al. An imbalance between the excretion of thromboxane and prostacyclin metabolites in pulmonary hypertension. $N$ Engl J Med 1992; 327: 70-75.

40. Dinh-Xuan AT, Higenbottam TW, Clelland CA, et al. Impairment of endothelium-dependent pulmonary artery relaxation in chronic obstructive lung disease. $N$ Engl $J$ Med 1991; 324: 1539-1547.

41. Esmon CT. The regulation of natural anticoagulant pathways. Science 1987; 235: 1348-1352.

42. Conway EM, Rosenberg RD. Tumor necrosis factor suppresses transcription of the thrombomodulin gene in endothelial cells. Mol Cell Biol 1988; 8: 5588-5592.

43. Humbert M, Monti G, Brenot F, et al. Serum IL-1, IL6 and TNF- $\alpha$ in primary pulmonary hypertension. Am J Respir Crit Care Med 1994; 149: A747.

44. Welsh CH, Marlar RA, Hassell KL. Coagulation activation, fibrinolysis and severity of pulmonary hypertension. Am J Respir Crit Care Med 1994; 149: A746.

45. Sakata Y, Okada M, Noro A, Matsuda M. Interaction of tissue-type plasminogen activator and plasminogen activator inhibitor- 1 on the surface of endothelial cells. J Biol Chem 1988; 263: 1960-1969.

46. Benotti JR, Ockene IS, Alpert JS, Dalen JE. The clinical profile of unresolved pulmonary embolism. Chest 1983; 84: 669-675.

47. Olman MA, Marsh JJ, Lang IM, Moser KM, Binder BR, Schleef RR. Endogenous fibrinolytic system in chronic large vessel thromboembolic pulmonary hypertension. Circulation 1992; 86: 1241-1248.

48. Schulman LL, Grossman BA, Owen J. Platelet activation and fibrinopeptide formation in pulmonary hypertension. Chest 1993; 104: 1690-1693. 
49. Huber K, Beckmann R, Frank H, Kneussl M, Mlczoch J, Binder BR. Fibrinogen, t-PA, and PAI-1 plasma levels in patients with pulmonary hypertension. Am J Respir Crit Care Med 1994; 150: 929-933.

50. Schultze AE, Roth RA. Procoagulant and fibrinolytic properties of bovine endothelial cells treated with monocrotaline pyrrole. Toxicol Appl Pharmacol 1993; 122: 7-15.

51. Schultze AE, Roth RA. Fibrinolytic activity in blood and lungs of rats treated with monocrotaline pyrrole. Toxicol Appl Pharmacol 1993; 121: 129-137.

52. Ware JA, Heistad DD. Seminars in medicine of the Beth Israel Hospital, Boston: platelet-endothelium interactions. $N$ Engl J Med 1993; 328: 628-635.

53. Heffner JE, Sahn SA, Repine JE. The role of platelets in the adult respiratory distress syndrome: culprits or bystanders? Am Rev Respir Dis 1987; 135: 482-492.

54. Schafer AI, Crawford DD, Gimbrone MA Jr. Unidirectional transfer of prostaglandin endoperoxides between platelets and endothelial cells. J Clin Invest 1984; 73: 1105-1112.

55. Heffner JE, Repine JE. Platelets. In: Crystal RG, West JB, Barnes PJ, Cherniack NS, Weibel ER, eds. The Lung: Scientific Foundations. New York, Raven press, 1991; pp. 617-630.

56. Merkow L, Kleinerman J. An electron microscopic study of pulmonary vasculitis induced by monocrotaline. $L a b$ Invest 1966; 15: 547-564.

57. Kanai Y, Hori S, Tanaka T, et al. Role of 5-hydroxytriptamine in the progression of monocrotaline-induced pulmonary hypertension in rats. Cardiovasc Res 1993; 27: 1619-1623.

58. Lee S-L, Wang WW, Lanzillo JJ, Fanburg BL. Serotonin produces both hyperplasia and hypertrophy of bovine pulmonary artery smooth muscle cells in culture. Am J Physiol 1994; 266: L46-52.

59. Pitt BR, Weng W, Steve AR, Blakely RD, Reynolds I, Davies P. Serotonin increases DNA synthesis in rat proximal and distal pulmonary vascular smooth muscle cells in culture. Am J Physiol 1994; 266: L178-186.

60. Pakala R, Willerson JT, Benedict CR. Mitogenic effect of serotonin on vascular endothelial cells. Circulation 1994; 90: 1919-1926.

61. McMahon TJ, Hood JS, Nossaman BD, Kadowik PJ. Analysis of responses to serotonin in the pulmonary vascular bed of the cat. J Appl Physiol 1993; 75: 93-102.

62. Crowley ST, Dempsey EC, Horwik KB, Horwik LD. Platelet-induced vascular smooth muscle cell proliferation is modulated by the growth amplification factors serotonin and adenosine diphosphate. Circulation 1994; 90: 1908-1918.

63. Herve P, Drouet L, Dosquet C, et al. Primary pulmonary hypertension in a patient with a familial platelet storage pool disease: role of serotonin. Am J Med 1990; 89: 117-120.

64. Herve P, Launay JM, Scrobohaci ML, et al. Increased plasma serotonin in primary pulmonary hypertension. Am J Med 1995; 99: 249-254.

65. Atanassoff PG, Weiss BM, Schmid ER, Tomic M. Pulmonary hypertension and dexfenfluramine. Lancet 1992 ; 339: 436.

66. Brenot F, Herve P, Petitpretz P, Parent F, Duroux P, Simonneau G. Primary pulmonary hypertension and fenfluramine use. Br Heart J 1993; 70: 537-541.

67. Triplett DA, Brandt JT. Lupus anticoagulants: misnomer, paradox, riddle, epiphenomenon. Hematol Pathol 1988; 2: $121-143$.

68. Asherson RA, Khamashta MA, Ordi-Ros J, et al. The "primary" antiphospholipid syndrome: major clinical and serological features. Medicine 1989; 68: 366-374.

69. Parke AL, Weinstein RE, Bona RD, Maier DB, Walker FJ. The thrombotic diathesis associated with the presence of phospholipid antibodies may be due to low levels of free protein S. Am J Med 1992; 93: 49-56.

70. Cariou R, Tobelem G, Soria C, Caen J. Inhibition of protein $\mathrm{C}$ activation by endothelial cells in the presence of lupus anticoagulant. N Engl J Med 1986; 314: 1193-1194.

71. Marciniak E, Romond EH. Impaired catalytic function of activated protein $\mathrm{C}$ : a new in vitro manifestation of lupus anticoagulant. Blood 1989; 74: 2426-2432.

72. Tsakiris DA, Marbet GA, Makris PE, Settas L, Duckert F. Impaired fibrinolysis as an essential contribution to thrombosis in patients with lupus anticoagulant. Thromb Haemost 1989; 61: 175-177.

73. Carreras LO, Vermylen JG. "Lupus" anticoagulant and thrombosis: possible role of inhibition of prostacyclin formation. Thromb Haemost 1982; 48: 38-40.

74. Reverter J-C, Tàssies D, Escolar G, et al. Effect of plasma from patients with primary antiphospholipid syndrome on platelet function in a collagen rich perfusion system. Thromb Haemost 1995; 73: 132-137.

75. Petraiuolo W, Bovill E, Hoak J. The lupus anticoagulant stimulates the release of prostacyclin from human endothelial cells. Thromb Res 1988; 50: 847-855.

76. Hughes GR. The antiphospholipid syndrome: ten years on. Lancet 1993; 342: 341-344.

77. Butt AY, Cremona G, Wood G, Katayama Y, Higenbottam TW. Anticardiolipin antibodies and pulmonary hypertension. Am J Respir Crit Care Med 1995; 151: A726.

78. Asherson RA, Higenbottam TW, Dinh Xuan AT, Khamashta MA, Hughes GR. Pulmonary hypertension in a lupus clinic: experience with twenty-four patients. J Rheumatol 1990; 17: 1292-1298.

79. Luchi ME, Asherson RA, Lahita RG. Primary idiopathic pulmonary hypertension complicated by pulmonary arterial thrombosis: association with antiphospholipid antibodies. Arthritis Rheum 1992; 35: 700-705.

80. Fuster V, Steele PM, Edwards WD, Gersh BJ, McGoon MD, Frye RL. Primary pulmonary hypertension: natural history and the importance of thrombosis. Circulation 1984; 70: 580-587.

81. Rich S, Kaufmann E, Levy PS. The effect of high doses of calcium-channel blockers on survival in primary pulmonary hypertension. N Engl J Med 1992; 327: 76-81.

82. Frank H, Gurtner HP, Kneussl M, Lang I, Mlczoch J. Aminorex-induzierte, plexogene pulmonale Arteriopathie: 25 Jahre danach. Z Kardiol 1993; 82: 568-572.

83. Higenbottam TW, Wheeldon D, Wells FC, Wallwork J. Long-term treatment of primary pulmonary hypertension with continuous intravenous prostacyclin (epoprostenol). Lancet 1984; i: 1046-1047.

84. Higenbottam TW, Spiegelhalter D, Scott JP, et al. Prostacyclin (epoprostenol) and heart-lung transplantation as treatments for severe pulmonary hypertension. $\mathrm{Br}$ Heart J 1993; 70: 366-370.

85. Barst RJ, Rubin LJ, McGoon MD, Caldwell EJ, Long WA, Levy PS. Survival in primary pulmonary hypertension with long-term continuous intravenous prostacyclin. Ann Intern Med 1994; 121: 409-415.

86. Butt AY, Cremona G, Katayama Y, Glanville C, Higenbottam TW. Effect of continuous infusion of prostacyclin $\left(\mathrm{PGI}_{2}\right)$ on survival in moderate and severe pulmonary hypertension. Am J Respir Crit Care Med 1994; 149: A748. 